JIEB (ISSN : 2442-4560) available online at : ejournal.stiepancasetia.ac.id

\title{
PENGARUH KEPEMIMPINAN, PENDIDIKAN DAN PELATIHAN, KOMPENSASI, DAN LINGKUNGAN KERJA TERHADAP KINERJA PEGAWAI KANTOR WILAYAH DIREKTORAT JENDERAL PERBENDAHARAAN PROVINSI KALIMANTAN SELATAN
}

\author{
Kun Sri Hartanto \\ Kanwil Direktorat Jenderal Perbendaharaan Provinsi Kalimantan Selatan \\ Jl. D.I. Panjaitan No. 4 Banjarmasin \\ e-mail: kumizara@gmail.com
}

\begin{abstract}
The purpose of this study was to determine the effect of leadership, education and training, compensation, and work environment on employee performance at Regional Office of Directorate General of Treasury of South Kalimantan Province. The population of this study were 79 people and 40 people samples by using purposive sampling technique. Data analysis technique using multiple linear regression analysis. The results showed that leadership, education and training, compensation, and work environment simultaneously and partially have a significant effect on employee performance, with education and training became the dominant factor influencing work performance.
\end{abstract}

Keywords: Leadership, Education and Training, Compensation, Work Environment, and Employee Performance.

Abstrak : Tujuan penelitian ini adalah untuk menguji pengaruh kepemimpinan, pendidikan dan pelatihan, kompensasi, dan lingkungan kerja terhadap kinerja pegawai pada Kantor Wilayah Direktorat Jenderal (Kanwil Ditjen) Perbendaharaan Provinsi Kalimantan Selatan. Populasi penelitian ini sebanyak 79 orang dengan sampel sebanyak 40 orang, menggunakan teknik pengambilan sampel purposive sampling. Teknik analisis data menggunakan analisis regresi linier berganda. Hasil penelitian menunjukkan bahwa kepemimpinan, pendidikan dan pelatihan, kompensasi, dan lingkungan kerja secara simultan maupun parsial berpengaruh positif signifikan terhadap kinerja pegawai, dengan faktor Pendidikan dan pelatihan yang menjadi faktor yg berpengaruh dominan terhadap kinerja pegawai.

Kata kunci : Kepemimpinan, Pendidikan dan Pelatihan, Kompensasi, Lingkungan Kerja, Kinerja Pegawai.

\section{Latar Belakang}

Di era globalisasi yang sangat ketat dengan persaingan di segala bidang, semua organisasi baik swasta maupun institusi pemerintah suka atau tidak suka dituntut untuk menghadapi persaingan tersebut. Agar dapat terjaga eksistensinya dibutuhkan keberanian suatu organisasi untuk menghadapi perubahan dan memenangkan persaingan. Untuk memenangkan persaingan tersebut harus didukung oleh sumber daya yang dimiliki baik sumber daya manusia, sumber daya fisik, sumber daya keuangan, dan sumber daya informasi. Sumber Daya
Manusia (SDM) merupakan aset utama dan bagian integral dari suatu organisasi, sumber daya yang dimiliki oleh organisasi seperti sumber daya fisik, sumber daya keuangan, dan sumber daya informasi tidak dapat memberikan hasil yang maksimal jika tidak didukung sumber daya manusia yang berkualitas. Menurut Douglas (1996) organisasi membutuhkan karyawan yang mampu bekerja lebih baik dan lebih cepat, sehingga dibutuhkan karyawan yang memiliki kinerja (job performance) yang tinggi. 
Menurut Wirawan (2009:5) kinerja merupakan keluaran yang dihasilkan oleh fungsi-fungsi atau indikator-indikator suatu pekerjaan atau suatu profesi dalam waktu tertentu dan kinerja karyawan merupakan hasil sinergi dari sejumlah faktor yaitu faktor internal karyawan (meliputi disiplin kerja, motivasi kerja, pengetahuan, dan keterampilan), lingkungan internal organisasi (meliputi kepemimpinan, strategi organisasi, visi dan misi, kompensasi, lingkungan kerja, struktur organisasi, pendidikan dan pelatihan, dan kebijakan organisasi), dan faktor lingkungan eksternal organisasi. Sementara Simanjuntak (2005:79) menyatakan bahwa faktor-faktor yang mempengaruhi kinerja adalah kompetensi individual, dukungan organisasi, dan dukungan manajemen (terkait dengan kemampuan manajerial para manajemen atau pimpinan).

Faktor penting yang menentukan kinerja karyawan dan kemampuan organisasi beradaptasi dengan perubahan lingkungan menurut Bass et.al (2003), Locander et al.(2002), dan Yammarino et al. (1993) adalah kepemimpinan. Kepemimpinan memegang peranan penting karena pimpinan adalah seseorang yang akan menggerakkan dan mengarahkan organisasi dalam pencapaian tujuan dan seorang pemimpin perusahaan harus memiliki kemampuan mempengaruhi dan memberi motivasi pada karyawannya, yang berdampak pada peningkatan kinerja (Sutrisno, 2011:213). Efektivitas kepemimpinan tergantung pada hubungan pemimpin dengan bawahan, dan berbagai gaya kepemimpinan yang digunakan dalam situasi dan kondisi tertentu (Timpe, 2000:127). Kepemimpinan berpengaruh terhadap kinerja pegawai sebagaimana dikemukakan oleh Jaka Alit W, IN \& Sintaasih, DK (2013) dan Fathur Rosy (2014) dalam penelitian yang telah mereka lakukan.

Selain kepemimpinan pendidikan dan pelatihan (Diklat) juga berpengaruh terhadap kinerja pegawai, menurut Husein (2005:12) diklat adalah program yang bertujuan untuk memperbaiki keterampilan dan teknik pelaksanaan kerja pegawai untuk kebutuhan sekarang, peningkatan dalam keilmuan, pengetahuan, kemampuan, sikap, dan kepribadian untuk menyiapkan karyawan memangku tugas di masa yang akan datang. Pendapat hampir senada juga dikemukakan oleh Peter F Drucker yang menyatakan bahwa kinerja dipengaruhi beberapa faktor dan salah satu faktor tersebut adalah diklat. Hal tersebut didukung hasil penelitian dari Jaka Alit W, IN \& Sintaasih, DK (2013), Fathur Rosy (2014), dan Mukhlisoh (2008) yang menyatakan bahwa Diklat mempunyai pengaruh yang signifikan terhadap kinerja pegawai.

Kompensasi juga mempunyai pengaruh dalam meningkatkan kinerja karyawan, dengan cara pemberian kompensasi yang adil oleh perusahaan (Dessler, 2007). Pendapat tersebut juga didukung oleh Henry Simamora (2003) yang menyatakan bahwa salah satu fase terpenting dari suatu pekerjaan menurut sebagian besar karyawan adalah tingkat bayaran yang diterima. Apabila kompensasi dikelola dengan benar maka akan membantu organisasi mencapai tujuannya dan memperoleh, memelihara, dan mempertahankan tenaga kerja yang produktif. Penelitian yang dilakukan oleh Fathur Rosy (2014), Mukhlisoh (2008), dan Meilinda (2015) juga mendukung pendapat tersebut.

Selain faktor tersebut di atas, lingkungan kerja juga berpengaruh terhadap kinerja karyawan. Menurut Nitisemito dalam Yahyo (2013) lingkungan kerja adalah segala sesuatu yang ada di sekitar para pekerja yang dapat mempengaruhi dirinya dalam menjalankan tugas-tugas yang dibeban kepadanya. Lingkungan kerja adalah kondisi material dan psikologis yang ada di dalam organisasi sehingga organisasi harus menyediakan lingkungan kerja yang memadai seperti lingkungan fisik (tata ruang kantor yang rapi dan nyaman, lingkungan kantor yang bersih, sirkulasi udara yang lancar, penerangan yang cukup, tempat ibadah dan lain-lain) serta lingkungan nonfisik (suasana kerja karyawan, kesejahteraan karyawan, hubungan antara sesama karyawan, hubungan dengan pimpinan). Lingkungan kerja yang layak adalah yang dapat mendukung pelaksanaan kerja sehingga karyawan mempunyai semangat kerja untuk meningkatkan kinerja 
karyawan. Hal tersebut didukung hasil penelitian yang dilakukan oleh Meilinda (2015) yang memperlihatkan bahwa lingkungan kerja berpengaruh secara signifikan terhadap kinerja pegawai.

Sebagai salah satu unit eselon satu pada Kementerian Keuangan, Direktorat Jenderal Perbendaharaan telah melaksanakan tiga pilar reformasi birokrasi yang dilaksanakan pada Kementerian Keuangan, yaitu: 1) Penataan organisasi, meliputi modernisasi dan pemisahan, penggabungan, serta penajaman fungsi, 2) Perbaikan proses bisnis, meliputi analisis dan evaluasi jabatan, analisa beban kerja, dan penyusunan Standard Operating Procedure (SOP), dan 3) Peningkatan manajemen SDM, meliputi penyelenggaraan pendidikan dan pelatihan berbasis kompetensi. Dalam hal sumber daya manusia, sebagai organisasi dengan SDM terbesar kedua di Kementerian Keuangan, Ditjen Perbendaharaan menitikberatkan peningkatan kompetensi SDM untuk mewujudkan visinya "Menjadi Pengelola Perbendaharaan Negara yang Unggul di Tingkat Dunia".

Berdasarkan hasil wawancara dengan pegawai Kanwil Ditjen Perbendaharaan Provinsi Kalimantan Selatan dan observasi lapangan ditemukan informasi bahwa ketidaktegasan dalam menghadapi pegawai yang tidak disiplin kerja dan kurang beraninya pimpinan dalam dalam mengambil keputusan terkait pemberian hukuman kepada pegawai yang tidak disiplin tersebut. Kemudian ditemukan adanya ketidakadilan dalam pemberian kompensasi terutama pemberian tunjangan kinerja di mana terdapat pegawai yang kontribusinya kurang terhadap organisasi namun mendapatkan tunjangan yang sama bahkan lebih besar dibandingkan pegawai yang lebih berkontribusi. Rendahnya minat pegawai, terutama pada level pelaksana untuk mengikuti diklat teknis membuat penyelesaian pekerjaan bergantung pada satu dua orang tertentu. Kurang representatifnya lingkungan kerja kantor terutama buruknya sanitasi air, tingkat kebisingan suara, pencahayaan yang kurang terang di beberapa fasilitas penunjang misalnya toliet.
Berdasarkan latar belakang tersebut, dapat dirumuskan permasalahan:

1. Apakah Kepemimpinan, Pendidikan dan Pelatihan, Kompensasi, dan Lingkungan Kerja berpengaruh signifikan secara parsial terhadap kinerja pegawai Kanwil Ditjen Perbendaharaan Provinsi Kalimantan Selatan?

2. Apakah Kepemimpinan, Pendidikan dan Pelatihan, Kompensasi, dan Lingkungan Kerja berpengaruh signifikan secara simultan terhadap kinerja pegawai Kanwil Ditjen Perbendaharaan Provinsi Kalimantan Selatan?

3. Manakah variabel yang berpengaruh dominan terhadap kinerja pegawai Kanwil Ditjen Perbendaharaan Provinsi Kalimantan Selatan?

\section{Kajian Literatur}

Kinerja adalah hasil atau tingkat keberhasilan seseorang secara keseluruhan selama periode tertentu di dalam melaksanakan tugas dibandingkan dengan berbagai kemungkinan, seperti standar hasil kerja, target atau sasaran atau kriteria yang telah ditentukan terlebih dahulu dan telah disepakati bersama (Rivai, dkk). Sedangkan Priansa, D.J. (2014:269) berpendapat bahwa kinerja merupakan hasil kerja yang dicapai pegawai dalam mengemban tugas dan pekerjaan yang berasal dari organisasi.

Definisi kinerja menurut Bambang Kusriyanto dalam A.A. Anwar Prabu Mangkunegara (2005: 9) adalah perbandingan hasil yang dicapai dengan peran serta tenaga kerja per waktu (lazimnya per jam). Hasibuan (2001:34) mengemukakan "kinerja (prestasi kerja) adalah suatu hasil kerja yang dicapai seseorang dalam melaksanakan tugas tugas yang dibebankan kepadanya yang didasarkan atas kecakapan, pengalaman, dan kesungguhan serta waktu". Pengertian kinerja atau prestasi kerja diberi batasan oleh Maier (dalam As'ad 1991:47) sebagai kesuksesan seseorang di dalam melaksanakan suatu pekerjaan. Lebih tegas lagi Lawler and Porer menyatakan bahwa kinerja adalah succesfull role achiement yang diperoleh seseorang dari perbuatanya (As' ad, 1991:46-47). Dari batasan tersebut 
As'ad menyimpulkan bahwa kinerja adalah hasil yang dicapai seseorang menurut ukuran yang berlaku untuk pekerja yang bersangkutan. Sedang Suprihanto (dalam Srimulyo,1999:33) mengatakan bahwa kinerja atau prestasi kerja seseorang karyawan pada dasarnya adalah hasil kerja seseorang karyawan selama periode tertentu dibandingkan dengan kemungkinan, misalnya standar, target/sasaran atau kinerja yang telah di tentukan terlebih dahulu dan telah disepakati bersama.

Sedangkan untuk menilai kinerja pegawai dilakukan sistem penilaian kinerja (performance appraisal) yang dikenal juga dengan performance rating, performance Assessment, employeeevalution, merit, rating, efficiency rating, service rating merupakan proses yang digunakan perusahaan untuk mengevaluasi job performance (Rivai, 2010-17).

Kepemimpinan menurut Greenberg dan Baron (2003:471) adalah proses bila satu individu mempengaruhi anggota kelompok yang lain terhadap pencapaian dari tujuan kelompok atau organisasi yang telah disepakati. Dalam teori tersebut terdapat proses "mempengaruhi", dan pendapat hampir sama dikemukakan oleh Jeff Madura dalam bukunya Pengantar Bisnis (2007), fungsi kepemimpinan adalah proses mempengaruhi kebiasaan-kebiasaan orang lain demi mencapai tujuan bersama. Kepemimpinan ini dapat meliputi bertindak selaku tokoh panutan dengan cara yang konsisten dengan rencana strategis perusahaan maupun dapat dan juga dapat meliputi proses komunikasi mengenai pekerjaan yang diberikan kepada pegawai dan kemungkinan metode-metode yang dapat dilakukan untuk menyelesaikan penugasanpenugasan tersebut.

Menurut Rivai (2005:2), dalam bukunya yang berjudul Kepemimpinan Dan Perilaku Organisasi menyatakan bahwa definisi kepemimpinan secara luas, adalah meliputi proses mempengaruhi dalam menentukan tujuan organisasi, memotivasi perilaku pengikut untuk mencapai tujuan, mempengaruhi interprestasi mengenai peristiwa-peristiwa para pengikutnya, pengorganisasian dan aktivitas-aktivitas untuk mencapai sasaran, memelihara hubungan kerja sama dan kerja kelompok, perolehan dukungan dan kerja sama dari orang-orang di luar kelompok atau organisasi.

Sedangkan kepemimpinan menurut George R. Terry (yang dikutip dari Sutarto, 1998:17) adalah hubungan yang ada dalam diri seseorang atau pemimpin, mempengaruhi orang lain untuk bekerja secara sadar dalam hubungan tugas untuk mencapai tujuan yang diinginkan. Young (dalam Kartono, 2003) mendefinisikan kepemimpinan sebagai bentuk dominasi yang didasari atas kemampuan pribadi yang sanggup mendorong atau mengajak orang lain untuk berbuat sesuatu yang berdasarkan penerimaan oleh kelompoknya, dan memiliki keahlian khusus yang tepat bagi situasi yang khusus. Menurut Hasibuan (2003:170) Kepemimpinan adalah cara seorang pemimpin mempengaruhi perilaku bawahan agar mau bekerja sama dan bekerja secara efektif dan efisien untuk mencapai tujuan organisasi.

Pendidikan dan pelatihan menurut Sumarsono, (2009 : 92-93) merupakan salah satu faktor yang penting dalam pengembangan SDM.Pendidikan dan latihannya tidak hanya menambah pengetahuan, akan tetapi juga meningkatkan keterampilan bekerja, dengan demikian meningkatkan produktivitas kerja.

Pendidikan dan pelatihan merupakan upaya untuk mengembangkan sumber daya manusia, terutama untuk mengembangkan kemampuan intelektual dan kepribadian manusia. Penggunaan istilah pendidikan istilah pendidikan dan pelatihan dalam suatu institusi atau organisasi biasanya disatukan menjadi diklat (Soekidjo 2003:28).

Definisi Pendidikan dan Pelatihan menurut Peraturan Pemerintah Nomor 101 tahun 2000 tentang Pendidikan dan Pelatihan Jabatan Pegawai Negeri Sipil Pasal 1 ayat (1) menjelaskan bahwa "Pendidikan dan pelatihan jabatan PNS adalah proses penyelenggaraan belajar mengajar dalam rangka meningkatkan kemampuan Pegawai Negeri Sipil (PNS)"

Menurut Wursanto (1989:60-61), ada berbagai manfaat pendidikan dan pelatihan 
pegawai yaitu: (1) Pendidikan dan pelatihan meningkatkan stabilitas pegawai, artinya hubungan pergantian dengan pegawai lainnya yang tidak hadir. (2) Pendidikan dan pelatihan dapat memperbaiki cara kerja pegawai, artinya pegawai lebih kreatif dalam menjalankan pekerjaannya. (3) Pendidikan dan pelatihan memberi manfaat yang sangat baik bagi pegawai, karena dengan pendidikan dan pelatihan pegawai dapat berkembang dengan cepat, efisien dan melaksanakan tugas dengan baik. (4) Pendidikan dan pelatihan memberi kesempatan bagi pegawai untuk mengembangkan diri.

Menurut Malayu S.P. Hasibuan (2002:54), kompensasi adalah semua pendapatan yang berbentuk uang, barang secara langsung atau tidak langsung yang diterima karyawan sebagai imbalan atas jasa yang diberikan kepada perusahaan.

Pengertian lain dari kompensasi adalah merupakan sesuatu yang diterima karyawan sebagai pengganti kontribusi jasa mereka pada perusahaan, pemberian kompensasi merupakan salah satu pelaksanaan fungsi MSDM yang berhubungan dengan semua jenis penghargaan individual sebagi pertukaran dalam melakukan tugas keorganisasian (Veithzal Rivai). Sedangakan Dessler (2005) menyatakan bahwa kompensasi karyawan merujuk pada semua bentuk bayaran atau imbalan bagi karyawan dan berasal dari pekerjaan mereka.

Menurut Marihot T.E. Hariandja (2007:244) kompensasi adalah keseluruhan balas jasa yang diterima pegawai sebagai akibat dari pelaksanaan pekerjaan di organisasi dalam bentuk uang atau lainnya yang dapat berupa gaji, upah, bonus, insentif, dan tunjangan lainnya seperti tunjangan kesehatan, tunjangan hari raya, uang makan, uang cuti, dan lain-lain.

Menurut Handoko sistem kompensasi sendiri mempunyai tiga komponen pokok, yaitu : (1) Upah dasar (based pay), merupakan komponen upah dasar bagi kebanyakan karyawan, dan pada umumnya berdasarkan hitungan waktu, seperti jam, hari, minggu, bulan atau per tahun. (2) Upah berdasar kinerja (performance related pay), berkaitan dengan monetary reward dengan basis ukuran atau merupakan upah yang didasarkan pada ukuran kinerja individu, kelompok atau organisasi. (3) Upah tidak langsung dikenal sebagai employee benefit "keuntungan bagi karyawan" terdiri dari barang-barang jasa non cash item atau services yang secara langsung memuaskan sejumlah kebutuhan spesifik karyawan, seperti jaminan keamanan pendapatan (income security) termasuk asuransi jiwa, perlindungan kesehatan termasuk medical \& dental plan, dan pensiun.

Menurut Nitisemito

(2001:183) mengemukakan bahwa, "Lingkungan kerja adalah segala sesuatu yang ada disekitar para pekerja yang dapat mempengaruhi dirinya dalam menjalankan tugas-tugas yang dibebankan, misalnya kebersihan, musik, dan lain-lain".

Sedangkan Sedarmayati (2011:2) mendefinisikan bahwa Lingkungan kerja maksudnya adalah keseluruhan alat perkakas dan bahan yang dihadapi, lingkungan sekitarnya di mana seseorang bekerja, metode kerjanya, serta pengaturan kerjanya baik sebagai perseorangan maupun sebagai kelompok .

Menurut Mardiana (2001:55) menjelaskan Lingkungan kerja adalah lingkungan di mana pegawai melakukan pekerjaannya sehari-hari. Lingkungan kerja terdiri dari a) kehidupan sosial, b) psikologi, dan c) fisik dalam perusahaan yang berpengaruh terhadap pekerjaan dalam melaksanakan tugasnya dikemukakan oleh Komarudin (1983:231).

A.A. Anwar Prabu Mangkunegara (2005:105), menyatakan bahwa "Lingkungan kerja adalah semua aspek fisik kerja, psikologis kerja dan peraturan kerja yang dapat mempengaruhi kepuasan kerja dan pencapaian produktivitas".

Menurut Supardi dalam Subroto (2005:23), menyatakan bahwa Lingkungan kerja merupakan keadaan sekitar tempat kerja baik secara fisik maupun non fisik yang dapat memberikan kesan yang menyenangkan, mengamankan, menenteramkan, dan betah dalam bekerja.

Terdapat dua jenis lingkungan kerja yaitu lingkungan kerja fisik dan nonfisik. Menurut Sedarmayanti (2009:21) menyatakan bahwa :"Secara garis besar, 
jenis lingkungan kerja terbagi menjadi 2 yakni: 1) lingkungan kerja fisik, dan 2) lingkungan kerja non-fisik”. Lingkungan kerja fisik adalah semua yang terdapat di sekitar tempat kerja yang dapat mempengaruhi pegawai baik secara langsung maupun tidak langsung. Lingkungan kerja non fisik adalah semua keadaan yang terjadi yang berkaitan dengan hubungan kerja, baik dengan atasan maupun dengan sesama rekan kerja ataupun hubungan dengan bawahan.

Hubungan positif Kepemimpinan dan Kinerja Pegawai dikemukakan oleh Gibson (2008) dan A. Dale Timple (1992) bahwa kepemimpinan merupakan salah satu faktor yang mempengaruhi kinerja pegawai. Hal tersebut didukung juga oleh hasil penelitian yang telah dilakukan Jaka Alit W, IN \& Sintaasih, DK (2013) dan Fathur Rosy (2014) yang menyatakan bahwa kepemimpinan mempunyai pengaruh positif dan signifikan terhadap kinerja pegawai

Sedangkan hubungan positif Diklat dan Kinerja Pegawai didukung teori yang dikemukakan oleh Peter F. Drucker (dalam Handoko, 1997:211) menyatakan bahwa diklat merupakan salah faktor penunjang dalam kinerja pegawai di samping faktor yang lain. Adapun hasil penelitian yang dilakukan oleh I.N. Jaka Alit dan D.K. Sinta Asih (2013) mendukung hasil penelitian ini, di mana hasil penelitian tersebut menemukan adanya pengaruh yang signifikan baik secara parsial maupun simultan Pendidikan dan Pelatihan terhadap Kinerja Pegawai. Penelitian ini juga didukung hasil penelitian Mukhlisoh (2008) yang menunjukkan bahwa Pendidikan dan Pelatihan berpengaruh signifikan terhadap kinerja pegawai dan Fathur Rosy (2014) yang juga membuktikan bahwa Pendidikan dan Pelatihan berpengaruh secara signifikan terhadap kinerja pegawai.

Untuk hubungan positif Kompensasi dan Kinerja Pegawai dikemukakan oleh Gibson (2008) yang menyatakan bahwa kompensasi berpengaruh signifikan terhadap kinerja pegawai. Di samping teori yang ada, penelitian ini sejalan pula dengan penelitian yang dilakukan oleh R. Meilinda (2015), Fathur Rosy (2014), dan Mukhlisoh (2008) yang juga membuktikan bahwa kompensasi berpengaruh signifikan terhadap kinerja pegawai.

Serta hubungan positif Lingkungan Kerja seperti teori yang dikemukakan oleh A. Dale Timple (1992) dan Gie dan Ibrahim (1999) yang menyatakan bahwa kinerja pegawai ditentukan oleh beberapa faktor dan salah satunya adalah lingkungan kerja pegawai. Hasil penelitian ini juga didukung oleh hasil penelitian R. Meilinda (2015) yang menyatakan bahwa Lingkungan Kerja berpengaruh secara signifikan terhadap Kinerja Pegawai.

Berdasarkan hasil kajian empiris berupa teori dan hasil penelitian sebelumnya maka dapat dirumuskan lima hipotesis sebagai berikut:

Hipotesis pertama : Kepemimpinan, Pendidikan dan Pelatihan, Kompensasi, dan Lingkungan kerja secara parsial berpengaruh positif dan signifikan terhadap kinerja pegawai Kanwil Ditjen Perbendaharaan Provinsi Kalimantan Selatan;

Hipotesis kedua: Kepemimpinan, Pendidikan dan Pelatihan, Kompensasi, dan Lingkungan kerja secara simultan berpengaruh signifikan terhadap kinerja pegawai Kanwil Ditjen Perbendaharaan Provinsi Kalimantan Selatan;

Hipotesis ketiga: Pendidikan dan Pelatihan secara dominan berpengaruh terhadap kinerja pegawai Kanwil Ditjen Perbendaharaan Provinsi Kalimantan Selatan.

\section{Metode Penelitian}

Penelitian ini menggunakan pendekatan kuantitatif dengan menggunakan analisis data berupa angka atau kualitatif yang diangkakan, sedangkan ditinjau dari tingkat kejelasan (eksplanasi) menggunakan pendekatan penelitian asosiatif yaitu penelitian dengan menghubungkan beberapa variabel penelitian (empat buah variabel bebas dan satu buah variabel terikat).

Populasi dalam penelitian ini adalah 79 pegawai pada Kanwil Ditjen Perbendaharaan Provinsi Kalimantan Selatan, sedangkan teknik pengambilan sampel adalah menggunakan teknik purposive sampling di mana hanya pegawai yang telah mengikuti diklat teknis dari tahun 2013 sampai dengan 
tahun 2016 yang dijadikan sampel yaitu 40 pegawai.

Tabel 1. Komposisi Responden (Sampel) Pegawai Kanwil Ditjen Perbendaharaan Provinsi Kalimantan Selatan

\begin{tabular}{clc}
\hline No & Bidang/Bagian & Jumlah Pegawai \\
\hline 1. & Bagian Umum & 13 \\
\hline 2. & Bidang PPA I & 9 \\
\hline 3. & Bidang PPA II & 7 \\
\hline 4. & Bidang PAPK & 8 \\
\hline 5. & Bidang SKKI & 3 \\
\hline & Jumlah & 40 \\
\hline
\end{tabular}

Sumber : Data Kanwil Dirjen Pembendaharaan Provinsi Kalimantan Selatan

Sumber data terdiri dari data primer yang diperoleh dari hasil jawaban kuesioner responden pegawai Kanwil Ditjen Perbendaharaan Provinsi Kalimantan Selatan, sedangkan data sekunder diperoleh dari laporan tertulis, peraturan, dokumentasi, buku. Metode pengumpulan data dalam penelitian ini menggunakan media kuesioner, wawancara, observasi, dan dokumentasi. Variabel Kepemimpinan, Diklat, Kompensasi, Lingkungan Kerja, dan Kinerja Pegawai Kanwil Ditjen Perbendaharaan Provinsi Kalimantan Selatan diukur dengan menggunakan skala likert dengan lima pilihan jawaban (Sangat setuju, setuju, raguragu, tidak setuju, dan sangat tidak setuju) dan selanjutnya akan dianalisis kemampuan variabel-variabel bebas untuk mempengaruhi variabel terikat menggunakan teknik analsis regresi linier berganda.

Variabel bebas dalam penelitian terdiri dari Kepemimpinan (X1), Diklat (X2), Kompensasi (X3), dan Lingkungan Kerja (X4), sedangkan variabel terikatnya adalah Kinerja Pegawai (Y). Kepemimpinan (X1) dalam penelitian ini adalah bagaimana pegawai (bawahan) dapat menerima, memahami, terpengaruh, dan memberikan penilaian terhadap kepemimpinan atasan diukur dengan menggunakan lima indikator dari Maryono yang terdiri dari kemampuan dalam melakukan analisa, keterampilan dalam berkomunikasi, keberanian pimpinan dalam mengambil keputusan, kemampuan dalam mendengar pendapat dan saran dari orang lain, dan mempunyai ketegasan terhadap bawahan.
Sedangkan Diklat (X2) adalah kegiatan yang diselenggarakan organisasi untuk meningkatkan kinerja pegawai, baik dalam kompetensi kerja, produktivitas, maupun keterampilan kerja yang dibutuhkan dalam suatu pekerjaan tertentu yang diukur dengan menggunakan enam indikator dari Rivai yang terdiri dari materi yang diajarkan, metode yang digunakan, sarana/fasilitas pendukung, kemampuan instruktur dalam menyampaikan materi, kemampuan peserta dalam menangkap materi dari instruktur, dan evaluasi hasil dari diklat yang diselenggarakan.

Kompensasi (X3) dalam penelitian ini adalah segala pemberian dari organisasi kepada pegawainya baik dalam bentuk uang/barang dan fasilitas lainnya disesuaikan dengan kontribusi pegawai terhadap organisasi diukur dengan lima indikator berdasarkan pendapat Simora dan Hasibuan yaitu gaji dan upah, insentif, tunjangantunjangan, fasilitas kerja, dan asuransi,

sedangkan Lingkungan Kerja (X4) adalah lingkungan di mana pegawai melakukan pekerjaannya sehari-hari yang dapat mempengaruhi dirinya dalam menjalankan tugas-tugas yang dibebankan yang diukur berdasarkan pendapat Sedarmayanti yang terdiri dari tujuh indikator antara lain penerangan (pencahayaan), suhu udara, suara bising, penggunaan warna (terutama untuk dinding dan dekorasi ruangan), ruang gerak yang diperlukan, keamanan kerja, dan hubungan antar pegawai.

Kinerja Pegawai (Y) sebagai variabel terikat adalah suatu hasil kerja yang dicapai oleh masing-masing pegawai dalam pelaksanaan tugas pekerjaan berdasarkan ukuran dan waktu yang telah ditentukan guna mewujudkan tujuan organisasi yang diukur menggunakan sembilan indikator dari Robbins dan Fadel yaitu kualitas kerja, kuantitas kerja, ketepatan waktu, efektivitas, kemandirian, pemahaman atas tupoksi, inovasi, kecepatan kerja, dan kerjasama.

Pengujian instrumen menggunakan mekanisme pengujian instrumen uji validitas, reliabilitas, dan uji asumsi publik yang terdiri dari uji Normalitas, Uji Heteroskedastisitas, Uji Multikolinieritas, Uji t, dan Uji F. Teknik 
analisis data yang digunakan adalah regresi linier berganda dengan pengolahan data menggunakan aplikasi SPSS Versi 21. Model regresi linier ganda adalah :

\section{$Y=a+b X 1+b X 2+b 3 X 3+c 4 X 4$}

Keterangan :

$\mathrm{Y}=$ Kinerja Pegawai

$\mathrm{a}=$ Konstanta

b1, b2, b3, b4 = Koefisien Regresi

$\mathrm{X} 1=$ Kepemimpinan

$\mathrm{X} 2=$ Pendidikan dan Pelatihan

$\mathrm{X} 3=$ Kompensasi

X4 = Lingkungan Kerja

\section{Hasil Penelitian dan Pembahasan}

Pada penelitian ini, karakteristik responden dijelaskan menurut Jenis Kelamin, Usia, Pendidikan, Masa Kerja, Jabatan, Status Perkawinan, dan Frekuensi Diklat. Karakteristik responden pegawai Kanwil Ditjen Perbendaharaan Provinsi Kalimantan Selatan berdasarkan jenis kelamin dapat dilihat pada tabel 2 .

Tabel 2. Jenis Kelamin Responden

\begin{tabular}{cccc}
\hline No & Jenis Kelamin & F & $\%$ \\
\hline 1. & Laki-Laki & 33 & 82,5 \\
\hline 2. & Perempuan & 7 & 17,5 \\
\hline & Jumlah & $\mathbf{4 0}$ & $\mathbf{1 0 0}$
\end{tabular}

Sumber : Hasil pengolahan data dengan SPSS 17

Dari tabel 2 sebagian besar responden berjenis kelamin laki-laki yaitu sebanyak 33 pegawai $(82,5 \%)$ dan berjenis kelamin perempuan sebanyak 7 pegawai $(17,5 \%)$.

Karakteristik responden berdasarkan usia ditunjukkan sebagaimana terlihat pada tabel 3 .

Tabel 3. Usia Responden

\begin{tabular}{cccc}
\hline No & Usia & $\mathrm{F}$ & $\%$ \\
\hline 1. & $20-30$ tahun & 0 & 0,0 \\
\hline 2. & $31-40$ tahun & 5 & 12,5 \\
\hline 3. & $41-50$ tahun & 12 & 30,0 \\
\hline 4. & $51-58$ tahun & 23 & 57,5 \\
\hline & Jumlah & $\mathbf{4 0}$ & $\mathbf{1 0 0}$
\end{tabular}

Sumber : Hasil pengolahan data dengan SPSS 17

Berdasarkan tabel 3 di atas, sebagian besar usia responden adalah usia antara 5158 tahun sebanyak 23 pegawai atau $57,5 \%$, kemudian diikuti usia antara 41-50 tahun sebanyak 12 pegawai atau $30 \%$, disusul usia antara 31-40 tahun sebanyak 5 pegawai atau $12,5 \%$. Sedangkan usia pegawai antara 20-30 tahun nihil $(0 \%)$. Hasil ini sejalan dengan jumlah populasi pada Kanwil Ditjen Perbendaharaan Provinsi Kalimantan Selatan yang didominasi oleh pegawai generasi baby boomers (pegawai kelahiran tahun 1945 sampai dengan tahun 1964) yang mencapai $67,09 \%$ (53 pegawai) dari 79 pegawai.

Sedangkan karakteristik responden berdasarkan pendidikan terakhir yang ditempuh dapat dilihat pada tabel 4 .

Tabel 4. Pendidkan Terakhir Responden

\begin{tabular}{clcc}
\hline No & \multicolumn{1}{c}{ Pendidikan } & F & $\%$ \\
\hline 1. & SLTA/D1 & 8 & 20,0 \\
\hline 2. & Sarjana Muda/D3 & 0 & 0,0 \\
\hline 3. & Sarjana (S1) & 23 & 57,5 \\
\hline 4. & Pascasarjana (S2) & 9 & 22,5 \\
\hline & Jumlah & 40 & 100
\end{tabular}

Sumber : Hasil pengolahan data dengan SPSS 17

Dari tabel 4 di atas bahwa responden penelitian ini sebagian besar berpendidikan terakhir sarjana (S1) sebanyak 23 pegawai $(57,5 \%)$, disusul lulusan pascasarjana (S2) sebanyak 9 pegawai $(22,5 \%)$, dan lulusan SLTA/D1 sebanyak 8 pegawai (20\%). Sedangkan responden yang berpendidikan terakhir sarjana muda/D3 nihil (0\%).

Karakteristik responden berdasarkan masa kerja dapat disajikan pada tabel 5.

\section{Tabel 5. Masa Kerja Responden}

\begin{tabular}{cccc}
\hline No & Masa Kerja & F & $\%$ \\
\hline 1. & $1-10$ tahun & 1 & 2,5 \\
\hline 2. & $11-20$ tahun & 12 & 30,0 \\
\hline 3. & $21-30$ tahun & 7 & 17,5 \\
\hline 4. & $>30$ tahun & 20 & 50,0 \\
\hline & Jumlah & $\mathbf{4 0}$ & $\mathbf{1 0 0}$
\end{tabular}

Sumber : Hasil pengolahan data dengan SPSS 17

Sejalan dengan usia responden yang lebih didominasi pegawai usia 51-58 tahun maka masa kerja pegawai juga lebih didominasi pegawai dengan masa kerja di atas 30 tahun yaitu sebanyak 20 pegawai (50\%), kemudian pegawai dengan masa kerja 11-20 tahun sebanyak 12 pegawai (30\%), disusul pegawai dengan masa kerja 21-30 tahun sebanyak 7 pegawai $(17,5 \%)$, dan pegawai dengan masa kerja 1-10 tahun sebanyak 1 pegawai $(2,5 \%)$. 
Adapun karakteristik responden berdasarkan jabatan dapat dilihat pada pada tabel 6.

Tabel 6. Jabatan Responden

\begin{tabular}{cccc}
\hline No & Jabatan & F & $\%$ \\
\hline 1. & Eselon 3 & 4 & 10,0 \\
\hline 2. & Eselon 4 & 15 & 37,5 \\
\hline 3. & Pelaksana & 21 & 52,5 \\
\hline & Jumlah & $\mathbf{4 0}$ & $\mathbf{1 0 0}$ \\
\hline
\end{tabular}

Sumber : Hasil pengolahan data dengan SPSS 17

Dari tabel di atas, responden penelitian sebagian besar adalah pegawai dengan jabatan pelaksana sebanyak 21 pegawai $(52,5 \%)$, diikuti pejabat eselon 4 sebanyak 15 pegawai $(37,5 \%)$, dan pejabat eselon 3 sebanyak 4 pegawai $(10 \%)$. Hal ini sesuai dengan piramida jabatan pada Kanwil Ditjen Perbendaharaan Provinsi Kalimantan Selatan, di mana jabatan semakin tinggi maka jumlahnya semakin mengerucut/ mengecil.

Menurut status perkawinan responden terdiri dua status yaitu menikah dan belum/tidak menikah, di mana hampir semua responden berstatus menikah sebanyak 39 pegawai $(97,5 \%)$ dan hanya 1 pegawai $(2,5 \%)$ yang berstatus belum/tidak menikah. Rincian tersebut dapat dilihat pada tabel 7.

Tabel 7. Status Perkawinan Responden

\begin{tabular}{clcc}
\hline No & Status Perkawinan & F & $\%$ \\
\hline 1. & Kawin & 39 & 97,5 \\
\hline 2. & Belum Kawin & 1 & 2,5 \\
\hline & Jumlah & 40 & 100 \\
\hline
\end{tabular}

Sumber : Hasil pengolahan data dengan SPSS 17

Karakteristik responden yang dipilah berdasarkan keikutsertaannya dalam diklat dapat dilihat pada tabel 8:

Tabel 8 Jumlah Keikutsertaan Diklat yang diikuti Respondenvdari Tahun 2013-2016

\begin{tabular}{clcc}
\hline No & Volume Diklat & F & $\%$ \\
\hline 1. & Sekali & 8 & 20,00 \\
\hline 2. & Dua kali & 16 & 40,00 \\
\hline 3. & Tiga kali & 13 & 32,50 \\
\hline 4. & Empat kali & 3 & 7,50 \\
\hline & Jumlah & 40 & 100 \\
\hline
\end{tabular}

Sumber : Hasil pengolahan data dengan SPSS 17

Dari tabel 8 di atas terlihat bahwa jumlah keikutsertaan pegawai pegawai Kanwil Ditjen Perbendaharaan Provinsi Kalimantan Selatan dalam mengikuti kegiatan diklat pada dalam kurun waktu tahun 2013 sampai dengan 2016 adalah frekuensi dua kali mengikuti diklat sebanyak 16 pegawai (40\%), kemudian tiga kali mengikuti diklat sebanyak 13 pegawai $(32,5 \%)$, disusul satu kali mengikuti diklat sebanyak 8 pegawai (20\%), dan empat kali mengikuti diklat sebanyak 3 pegawai $(7,5 \%)$.

Hasil Uji Validitas dan Reliabilitas hasilnya menunjukkan bahwa instrumen penelitan valid dan reliabel. Pengukuran validitas menggunakan product moment pearson correlation di mana hasilnya $\mathrm{r}$ hitung pada semua instrumen lebih besar dari $\mathrm{r}$ tabel sebesar 0,312 ( $\mathrm{r}$ hitung > $\mathrm{r}$ tabel), sedangkan hasil uji Reliabilitas menunjukkan semua variabel bebas (X1, X2, X3, X4) mempunyai nilai Chronbach's Alpha $>0,60$ yang artinya adalah reliabel (andal).

Hasil uji asumsi klasik yang terdiri dari uji normalitas, heteroskedastisitas, dan multikolinieritas menunjukkan bahwa semua data pada variabel penelitian memiliki distribusi normal, bebas heteroskedastisitas, dan bebas multikolinieritas. Uji normalitas menggunakanuji normalitas Kolmogorov Smirnov menunjukkan nilai signifikansi 0,831 (nilai pada Asyimp. Sig. (2-tailed) yang berarti di atas 0,05 atau data dalam variabel penelitian ini memiliki distribusi normal. Sedangkan hasil uji heteroskedastisitas menggunakan uji glejser menunjukkan terlihat bahwa nilai sig. kepemimpinan, diklat, kompensasi, dan lingkungan kerja sebesar 0,532, 0,867, 0,166, dan 0,312 masih di atas nilai signifikansi (sig.) 0,05 sehingga semua variabel bebas yang digunakan dalam penelitian dinyatakan tidak terdapat heteroskedastisitas. Sedangkan uji multikolinieritas menunjukkan semua nilai variabel bebas (independen) bernilai tollerance $>010$ dan nilai Variabel Inflation Factors (VIF) $<10$ sehingga dinyatakan bebas dari multikolinieritas.

Tahapan selanjutnya adalah analisis regresi linear berganda untuk mengetahui kemampuan dari kepemimpinan, diklat, kompensasi dan lingkungan kerja dalam mempengaruhi kinerja pegawai pada Kanwil Ditjen Perbendaharaan Provinsi Kalimantan Selatan. Hasil dari analisis regresi linier berganda menggunakan uji t dan uji f dapat dilihat pada tabel 9 . 
Tabel 9. Hasil Regresi Linier Berganda

\begin{tabular}{|c|c|c|c|c|c|c|}
\hline & Variabel & Unstand & rdized & Standardized & $\mathrm{t}$ & Sig. \\
\hline & & $B$ & Std. Error & Beta & & \\
\hline 1 & (Constant) & 17.567 & 5.439 & & 3.230 & .003 \\
\hline & Kepemimpinan & .271 & .092 & .222 & 2.944 & .006 \\
\hline & Diklat & .366 & .142 & .273 & 2.580 & .014 \\
\hline & Kompensasi & .224 & .182 & .182 & 2.519 & .012 \\
\hline & Lingkungan Kerja & 180 & .198 & .176 & 2.906 & .000 \\
\hline
\end{tabular}

\begin{tabular}{llr}
\hline $\mathrm{R}$ & $=0,863$ \\
Adjusted R Square & $=0,745$ \\
F hitung & $=25,604$ \\
Sig. F hitung & $=0,000$
\end{tabular}

Sumber : Hasil pengolahan data dengan SPSS 17

Hasil uji t menunjukkan bahwa secara parsial variabel kepemimpinan, diklat, kompensasi, dan lingkungan kerja mempunyai pengaruh positif dan signifikan terhadap kinerja pegawai Kanwil Ditjen Perbendaharaan Provinsi Kalimantan Selatan, yaitu $\mathrm{t}$ hitung nilai $>$ dari $\mathrm{t}$ tabel $(\mathrm{t}$ hitung > 2,030) dengan nilai signifikansi < 0,05 . Sedangkan variabel dominan yang berpengaruh terhadap kinerja pegawai Kanwil Ditjen Perbendaharaan Provinsi Kalimantan Selatan adalah Diklat, terlihat pada nilai Standardized Coefficients Beta sebesar 0,273.

Hasil Uji $F$ menunjukkan bahwa $F$ hitung sebesar 25,605 > F tabel sebesar 2,64 dengan nilai Sig. F hitung sebesar 0,000 lyang berarti bahwa kepemimpinan, diklat, kompensasi, dan lingkungan kerja secara simultan berpengaruh positif dan signifikan terhadap kinerja pegawai Kanwil Ditjen Perbendaharaan Provinsi Kalimantan Selatan.

Hasil uji hipotesis membuktikan bahwa kepemimpinan, pendidikan dan pelatihan, kompensasi, dan lingkungan kerja secara parsial mempunyai pengaruh positif dan signifikan terhadap kinerja pegawai Kanwil Ditjen Perbendaharaan Provinsi Kalimantan Selatan, hal ini menunjukkan bahwa kepemimpinan yang diukur berdasarkan dari kemampuan pemimpin dalam melakukan analisis, keterampilan dalam berkomunikasi, keberanian dalam pengambilan keputusan, kemampuan mendengar pendapat dan saran serta memiliki ketegasan terhadap bawahan memiliki pengaruh signifikan terhadap kinerja pegawai Kanwil Ditjen Perbendaharaan Provinsi Kalimantan Selatan.

Adapun kinerja pegawai diukur dari kualitas kerja berupa ketelitian dalam menyelesaikan pekerjaan, kuantitas kerja berupa kemampuan dalam menyelesaikan pekerjaan, ketepatan waktu berupa kemampuan menyelesaikan pekerjaan sesuai tenggat waktu yang telah ditetapkan, efektivitas berupa kemampuan dalam menyelesaikan pekerjaan sesuai dengan target yang telah ditetapkan, kemandirian pegawai berupa inisiatif melaksanakan pekerjaan tanpa harus menunggu perintah atasan, pemahaman pegawai terhadap tugas pokok dan fungsi pekerjaan sehari-hari, inovasi berupa dukungan pegawai terhadap suatu inovasi yang positif, kecepatan kerja berupa seberapa cepat dalam menyelesaikan pekerjaan, dan kerja sama berupa kemampuan bekerja sama dalam satu tim.

Hasil penelitian ini sesuai dengan teori yang dikemukakan oleh Gibson (2008) dan A. Dale Timple (1992) bahwa kepemimpinan merupakan salah satu faktor yang mempengaruhi kinerja pegawai. Hasil penelitian ini juga sejalan dengan penelitian yang dilakukan oleh I.N. Jaka Alit dan D.K. Sinta Asih (2013) di mana terbukti bahwa kepemimpinan baik secara parsial maupun simultan berpengaruh terhadap kinerja pegawai.Hasil penelitian tersebut didukung 
pula hasil penelitian yang dilakukan oleh Fathur Rossy (2014) yang membuktikan bahwa kepemimpinan memiliki pengaruh yang positif dan signifikan terhadap kinerja pegawai.

Hasil uji hipotesis membuktikan bahwa Pendidikan dan Pelatihan berpengaruh secara signifikan terhadap Kinerja pegawai Kanwil Ditjen Perbendaharaan Provinsi Kalimantan Selatan, hal ini membuktikan bahwa kesesuaian materi diklat dengan bidang pekerjaan, ketepatan metode pengajaran yang diberikan, kemampuan pengajar dalam menyampaikan materi diklat, pemberian evaluasi terhadap pelaksanaan diklat, sarana dan prasarana diklat yang memadai, serta adanya indikasi peningkatan kemampuan peserta diklat berkontribusi positif terhadap kinerja pegawai Kanwil Ditjen Perbendaharaan Provinsi Kalimantan Selatan.

Kinerja dalam penelitian ini dilihat dari kualitas kerja berupa ketelitian dalam menyelesaikan pekerjaan, kuantitas kerja berupa kemampuan dalam menyelesaikan pekerjaan, ketepatan waktu berupa kemampuan menyelesaikan pekerjaan sesuai tenggat waktu yang telah ditetapkan, efektivitas berupa kemampuan dalam menyelesaikan pekerjaan sesuai dengan target yang telah ditetapkan, kemandirian pegawai berupa inisiatif melaksanakan pekerjaan tanpa harus menunggu perintah atasan, pemahaman pegawai terhadap tugas pokok dan fungsi pekerjaan sehari-hari, inovasi berupa dukungan pegawai terhadap suatu inovasi yang positif, kecepatan kerja berupa seberapa cepat dalam menyelesaikan pekerjaan, dan kerja sama berupa kemampuan bekerja sama dalam satu tim.

Hasil penelitian ini didukung teori yang dikemukakan oleh Peter F. Drucker (dalam Handoko, 1997:211) menyatakan bahwa diklat merupakan salah faktor penunjang dalam kinerja pegawai di samping faktor yang lain. Adapun hasil penelitian yang dilakukan oleh I.N. Jaka Alit dan D.K. Sinta Asih (2013) mendukung hasil penelitian ini, di mana hasil penelitian tersebut menemukan adanya pengaruh yang signifikan baik secara parsial maupun simultan Pendidikan dan Pelatihan terhadap
Kinerja Pegawai. Penelitian ini juga didukung hasil penelitian Mukhlisoh (2008) yang menunjukkan bahwa Pendidikan dan Pelatihan berpengaruh signifikan terhadap kinerja pegawai dan Fathur Rosy (2014) yang juga membuktikan bahwa Pendidikan dan Pelatihan berpengaruh secara signifikan terhadap kinerja pegawai.

Hasil uji hipotesis membuktikan bahwa Kompensasi berpengaruh signifikan terhadap Kinerja Pegawai Kanwil Ditjen Perbendaharaan Provinsi Kalimantan Selatan. Hal ini membuktikan bahwa pemberian gaji yang tepat waktu, besaran nilai insentif yang diterima setiap tahun, besaran nilai tunjangan yang diterima setiap bulan, asuransi yang bisa memberikan rasa aman, dan fasilitas kerja yang memadai memberikan kontribusi yang positif terhadap kinerja pegawai Kanwil Ditjen Perbendaharaan Provinsi Kalimantan Selatan. Kinerja dalam penelitian ini dilihat dari kualitas kerja berupa ketelitian dalam menyelesaikan pekerjaan, kuantitas kerja berupa kemampuan dalam menyelesaikan pekerjaan, ketepatan waktu berupa kemampuan menyelesaikan pekerjaan sesuai tenggat waktu yang telah ditetapkan, efektivitas berupa kemampuan dalam menyelesaikan pekerjaan sesuai dengan target yang telah ditetapkan, kemandirian pegawai berupa inisiatif melaksanakan pekerjaan tanpa harus menunggu perintah atasan, pemahaman pegawai terhadap tugas pokok dan fungsi pekerjaan sehari-hari, inovasi berupa dukungan pegawai terhadap suatu inovasi yang positif, kecepatan kerja berupa seberapa cepat dalam menyelesaikan pekerjaan, dan kerja sama berupa kemampuan bekerja sama dalam satu tim.

Hasil penelitian ini sesuai dengan teori yang dikemukakan oleh Gibson (2008) yang menyatakan bahwa kompensasi berpengaruh signifikan terhadap kinerja pegawai. Di samping teori yang ada, penelitian ini sejalan pula dengan penelitian yang dilakukan oleh R. Meilinda (2015), Fathur Rosy (2014), dan Mukhlisoh (2008) yang juga membuktikan bahwa kompensasi berpengaruh signifikan terhadap kinerja pegawai.

Hasil uji hipotesis membuktikan bahwa Lingkungan Kerja berpengaruh positif dan 
signifikan terhadap Kinerja Pegawai pada Kanwil Ditjen Perbendaharaan Provinsi Kalimantan Selatan. Hal tersebut membuktikan bahwa pengaturan temperatur yang sesuai, pengaturan cahaya yang tidak menyilaukan, ruangan kerja yang jauh dari kebisingan, penggunaan warna yang lembut di ruang kerja, adanya jaminan keamanan, hubungan yang harmonis di antara pegawai, dan ruang kerja yang dapat memberikan ruang gerak pegawai dapat meningkatkan kinerja pegawai Kanwil Ditjen Perbendaharaan Provinsi Kalimantan Selatan.

Adapun kinerja dalam penelitian ini dilihat dari kualitas kerja berupa ketelitian dalam menyelesaikan pekerjaan, kuantitas kerja berupa kemampuan dalam menyelesaikan pekerjaan, ketepatan waktu berupa kemampuan menyelesaikan pekerjaan sesuai tenggat waktu yang telah ditetapkan, efektivitas berupa kemampuan dalam menyelesaikan pekerjaan sesuai dengan target yang telah ditetapkan, kemandirian pegawai berupa inisiatif melaksanakan pekerjaan tanpa harus menunggu perintah atasan, pemahaman pegawai terhadap tugas pokok dan fungsi pekerjaan sehari-hari, inovasi berupa dukungan pegawai terhadap suatu inovasi yang positif, kecepatan kerja berupa seberapa cepat dalam menyelesaikan pekerjaan, dan kerja sama berupa kemampuan untuk bekerja sama dalam satu tim.

Hasil penelitian ini sejalan dengan teori yang dikemukakan oleh A. Dale Timple (1992) dan Gie dan Ibrahim (1999) yang menyatakan bahwa kinerja pegawai ditentukan beberapa faktor dan salah satunya adalah lingkungan kerja pegawai. Hasil penelitian ini juga didukung oleh hasil penelitian R. Meilinda (2015) yang menyatakan bahwa Lingkungan Kerja berpengaruh secara signifikan terhadap Kinerja Pegawai.

Hasil uji $F$ membuktikan bahwa Kepemimpinan, Pendidikan dan Pelatihan, Kompensasi, dan Lingkungan Kerja secara bersama-sama (simultan) memberikan pengaruh yang positif dan signifikan terhadap Kinerja Pegawai pada Kanwil Ditjen Perbendaharaan Provinsi Kalimantan
Selatan. Hal tersebut berarti bahwa adanya kepemimpinan yang mampu menggerakkan bawahan (organisasi), penugasan diklat yang lebih merata kepada semua pegawai, Kompensasi yang lebih yang mengedepankan keadilan, dan lingkungan kerja yang lebih nyaman dapat meningkatkan Kinerja Pegawai Kanwil Ditjen Perbendaharaan Provinsi Kalimantan Selatan diukur berdasarkan indicator dari kualitas kerja berupa ketelitian dalam menyelesaikan pekerjaan, kuantitas kerja berupa kemampuan dalam menyelesaikan pekerjaan, ketepatan waktu berupa kemampuan menyelesaikan pekerjaan sesuai tenggat waktu yang telah ditetapkan, efektivitas berupa kemampuan dalam menyelesaikan pekerjaan sesuai dengan target yang telah ditetapkan, kemandirian pegawai berupa inisiatif melaksanakan pekerjaan tanpa harus menunggu perintah atasan, pemahaman pegawai terhadap tugas pokok dan fungsi pekerjaan sehari-hari, inovasi berupa dukungan pegawai terhadap suatu inovasi yang positif, kecepatan kerja berupa seberapa cepat dalam menyelesaikan pekerjaan, dan kerja sama berupa kemampuan untukbekerja sama dalam satu tim.

Hasil penelitian ini sejalan dengan hasil penelitian oleh I.N. Jaka Alit dan D.K. Sinta Asih (2013), dan Fathur Rossy (2014) yang membuktikan bahwa kepemimpinan dan Pendidikan dan Pelatihan berpengaruh positif dan signifikan terhadap kinerja pegawai. Hasil penelitian ini juga sejalan dengan penelitian R. Meilinda (2015) dan Mukhlisoh (2008) yang membuktikan bahwa Kompensasi dan Lingkungan Kerja berpengaruh secara signifikan terhadap Kinerja Pegawai Kanwil Ditjen Perbendaharaan Provinsi Kalimantan Selatan.

Berdasarkan temuan penelitian, diketahui bahwa pendidikan dan Pelatihan merupakan variabel yang dominan pengaruhnya terhadap kinerja pegawai Kanwil Ditjen Perbendaharaan Provinsi Kalimantan Selatan diikuti oleh Kepemimpinan, Kompensasi, dan yang paling akhir adalah variabel Lingkungan Kerja. Hasil ini membuktikan bahwa hipotesis yang menyatakan bahwa 
pendidikan dan pelatihan variabel dominan terhadap kinerja pegawai Kanwil Ditjen Perbendaharaan Provinsi Kalimantan Selatan terbukti secara signifikan.

\section{Kesimpulan}

Hasil pengujian pengaruh dari kepemimpinan, diklat, kompensasi, dan lingkungan kerja terhadap kinerja pegawai di Kanwil Ditjen Perbendaharaan Provinsi Kalimantan Selatan secara parsial menunjukkan bahwa variabel Kepemimpinan, Pendidikan dan Pelatihan, Kompensasi, dan Lingkungan Kerja semuanya memiliki pengaruh positif dan signifikan terhadap Kinerja Pegawai pada Kanwil Ditjen Perbendaharaan Provinsi Kalimantan Selatan;

Hasil dari pengujian secara simultan tentang pengaruh bersama dari variabel Kepemimpinan, Pendidikan dan Pelatihan, Kompensasi, dan Lingkungan Kerja terhadap Kinerja Pegawai Kanwil Ditjen Perbendaharaan Provinsi Kalimantan Selatan, menunjukkan bahwa terdapat pengaruh yang signifikan secara simultan oleh gabungan dari Kepemimpinan, Pendidikan dan Pelatihan, Kompensasi, dan Lingkungan Kerja terhadap Kinerja Pegawai Kanwil Ditjen Perbendaharaan Provinsi Kalimantan Selatan.

Dari keempat variabel bebas yang digunakan, yaitu kepemimpinan, pendidikan dan pelatihan, kompensasi, dan lingkungan kerja, ternyata variabel yang dominan yang mempengaruhi Kinerja Pegawai Kanwil Ditjen Perbendaharaan Provinsi Kalimantan Selatan adalah variabel Pendidikan dan Pelatihan.

Saran yang dapat diberikan kepada Kanwil Ditjen Perbendaharaan Provinsi Kalimantan Selatan adalah pimpinan pada Kanwil Ditjen Perbendaharaan Provinsi Kalimantan Selatan agar memberikan prioritas kepada pegawai yang belum pernah mengikuti kegiatan Diklat untuk diikutkan Diklat sehingga diharapkan kompetensi pegawai akan meningkat, dan selanjutnya tingkat ketergantungan terhadap satu atau dua orang pegawai dapat dikurangi atau dihilangkan.

$$
\text { Pimpinan Kanwil Ditjen }
$$

Perbendaharaan Provinsi Kalimantan Selatan agar lebih berani dalam mengambil keputusan strategis dan lebih tegas untuk menindak pegawai yang tidak disiplin masuk bekerja, karena berdasarkan penelitian ini Kepemimpinan terbukti mempunyai pengaruh yang positif dan signifikan terhadap Kinerja Pegawai Kanwil Ditjen Perbendaharaan Provinsi Kalimantan Selatan, sehingga apabila pimpinan dapat bertindak tegas dan berani dalam mengambil keputusan strategis maka dapat dipastikan Kinerja Pegawai Kanwil Ditjen Perbendaharaan Provinsi Kalimantan Selatan akan meningkat.

Agar pimpinan Kanwil Ditjen Perbendaharaan Provinsi Kalimantan Selatan memperbaiki sarana dan prasarana kantor yang merupakan lingkungan kerja pegawai sehingga dengan adanya perbaikan tersebut kinerja pegawai Kanwil Ditjen Perbendaharaan Provinsi Kalimantan Selatan akan meningkat karena berdasarkan hasil penelitian ini terdapat korelasi positif dan signifikan Lingkungan Kerja dengan Kinerja Kanwil Ditjen Perbendaharaan Provinsi Kalimantan Selatan.

Formulasi penilaian kinerja dan sistem grading agar dapat ditinjau ulang karena dalam sistem penilaian kinerja masih dijumpai adanya Indikator Kinerja Utama (IKU) pegawai yang menjadi IKU bersama dan sistem grading yang hanya menekankan faktor pendidikan dan kurang memberikan porsi terhadap kemampuan (ability), pengetahuan (knowledge), dan keterampilan (skill) pegawai dan sumbangsih yang diberikan dalam pelaksanaan pekerjaan sehari-hari di kantor.

Pada penelitian selanjutnya perlu menambahkan variabel bebas seperti motivasi kerja, disiplin kerja, dan budaya organisasi dengan pertimbangan variabel tersebut kemungkinan dapat mempengaruhi secara langsung terhadap kinerja pegawai Kanwil Ditjen Perbendaharaan Provinsi Kalimantan Selatan, juga perlu memperluas objek penelitian dengan melibatkan pegawai Kanwil Ditjen Perbendaharaan Provinsi Kalimantan Selatan yang belum pernah mengikuti diklat sebelum tahun 2013 sampai 
dengan tahun 2016, atau dengan melibatkan pegawai pada kantor vertikal lingkup Kanwil Ditjen Perbendaharaan Provinsi Kalimantan Selatan seperti KPPN Banjarmasin, KPPN Barabai, KPPN Tanjung, KPPN Pelaihari, dan KPPN Kotabaru sehingga hasilnya diharapkan akan lebih komprehensif.

\section{DAFTAR PUSTAKA}

Ardana, Komang, Ni Wayan Mujiati, dan I WayanMudiartha Utama. 2011. Manajemen SumberDaya Manusia, Edisi 1.Penerbit Graha Ilmu. Yogyakarta.

Arikunto, Suharsimi. 2014. Prosedur Penelitian: Suatu Pendekatan Praktik. Penerbit Rineka Cipta. Jakarta.

Armanu Thoyib.2005. Hubungan Kepemimpinan, Budaya, Strategi, dan Kinerja:Pendekatan Konsep. Jurnal Manajemen \& Kewirausahaan. Volume 7. Nomor 1. pp 60-73

As'ad.2003.Kepemimpinan

Dalam.Perusahaan. Edisi kedua. Penerbit Liberty. Yogyakarta.

Bacal, Robert. 2002. Performance Management. Penerbit PT Gramedia Pustaka Utama. Jakarta.

Dessler, Gary. 2003.Human Resource Management, Ninth Edition, PrenticeHall.

Drucker, Peter F. 1986. Bagaimana Menjadi Eksekutif yang Efektif. Penerbit Pedoman Ilmu Jaya. Jakarta.

Fathur Rosy, MM. 2014. Pengaruh Kompensasi, Pelatihan, dan Kepemimpinan Manajer Terhadap Kinerja Agen Pemasaran PT Asuransi Takaful Keluarga Representative Office (RO)

Sidoarjo.http://digilib.uinsby.ac.id 11089/ (diakses tanggal 4 Januari 2017)

Flippo, B. Edwin.2002.Manajemen Personalia.Edisi Keenam. Penerbit Erlangga. Jakarta.

Gibson, et.al. 2011. Organisasi: Perilaku, Struktur, Proses. Penerbit P.T. Binarupa Aksara. Tangerang.

Gie, The Liang. 2009. Administrasi Perkantoran Modern. Penerbit Liberty. Yogyakarta.
Greenberg, Jerald dan Baron, Robert A. 2000.Perilaku Organisasi.Penerbit Prentice Hall. Jakarta.

Handoko, T. Hani. 2003. Manajemen. Edisi Tiga. BPFE, Yogyakarta.

Hasibuan, Melayu S.P. 2007. Manajemen SumberDaya Manusia. Edisi Revisi. Penerbit P.T. Bumi Aksara, Jakarta.

Husein, Umar. 2005. Evaluasi Kinerja Perusahaan. Penerbit Gramedia Pustaka Utama. Jakarta.

I Nyoman Jaka Alit Wiratama dan Desak Ketut Sintaasih, 2013. Pengaruh Kepemimpinan, Diklat, dan Disiplin Kerja Terhadap Kinerja Karyawan PDAM Tirta Mangutama Kabupaten Badung. Volume 7, Nomor 2. 9 halaman.

J. Long, R. 1998. Compensation in Canada. ITP Nelson. Canada.

Junaidi. Aang. 2015. Analisis Persepsi SDM Multi-generasi Terhadap FaktorFaktor YangMempengaruhi Kinerja pada Kanwil Ditjen Perbendaharaan Provinsi KalimantanSelatan. Badan Penerbit Kanwil Ditjen Perbendaharaan Provinsi Kalimantan Selatan. Banjarmasin.

Kadir. 2015. StatistikaTerapan. Edisi Kedua. Penerbit P.T. Raja Grafindo Persada. Jakarta.

Kartono, K. 2010. Pemimpin dan Kepemimpinan. Edisi Revisi. Penerbit P.T. Raja Grafindo Persada. Jakarta.

Lewa, Eka Idham Iip K. dan Subowo. 2005. Pengaruh Kepemimpinan, lingkungan Kerja Fisik Dan Kompensasi Terhadap Kinerja Karyawan di P.T. Pertamina (Persero) Daerah Operasi Hulu Jawa Bagian Barat, Cirebon. Jurnal Sinergi Edisi Khusus on Human Resources, pp 126-140.

Madura. Jeff. 2007. Pengantar Bisnis. Edisi kedua. Penerbit Salemba Empat. Jakarta

Mangkunegara, A.P. 2005 Evaluasi Kinerja SDM. Penerbit P.T. Refika Aditama.Bandung.

Mangkunegara,

A.

$\mathrm{P}$. 2006.ManajemenSumber Daya Manusia Perusahaan, PenerbitPT. RemajaRosda Karya.Bandung. 
Mardiana. 2005. Manajemen Produksi. Penerbit Badan Penerbit IPWI. Jakarta.

Marihot Tua Efendi, Hariandja. 2002.Manajemen Sumber Daya Manusia : pengadaan, pengembangan, pengkompensasian, dan peningkatan produktivitas pegawai. Grasindo. Jakarta.

Martoyo, Susilo. 2007. Manajemen Sumber DayaManusia. Edisi 5. Penerbit BPFE. Yogyakata.

Mathis, Robert L and John H Jackson. 2003.Human

Management.Tenth resource

Thomson

Edition.

South-

Western.Ohio.

Maxwell, J.C. 2013. 5 Levels of Leadership. FirstEdition. MIC Publishing. New York.

Meilinda, R. 2015. Pengaruh Lingkungan Kerja, Motivasi, dan Kompensasi Terhadap kinerja Karyawan pada Tidar Foods Industries Kediri. https://simki.unpkediri.ac.id/mahasiswa /file_artikel/2015/10.1.02.02.0191.pdf. (diakses tanggal 7 Januari 2017).

Mondy, R. Wayne.1990. Human resource management. Allyn and Bacon Publish. Boston.

Muhammad, Fadel. 2009. Governance Reform di Indonesia: Mencari Arah Kelembagaan Politik yang Demokratis dan Birokrasi yang Profesional. Penerbit Gaya Media. Yogyakarta.

Mukhlisoh, N. 2008. Pengaruh Pendidikan dan Pelatihan, kompensasi, dan Kepuasan Kerja Guru Terhadap Kinerja Guru Madrasah Tsanawiyah Swasta Kecamatan Bulakamba Brebes.Tesis. Program Studi Manajemen Pendidikan Universitas Negeri Semarang.

Nazir, M. 2014. Metode Penelitian. Edisi Kesembilan. Penerbit Ghalia Indonesia. Bogor.

Neolaka, Amos. 2014. Metode Penelitian dan Statistik. Cetakan Pertama. Penerbit P.T. Remaja Rosda Karya. Bandung.
Nitisemito, Alex. 2001. Manajemen Personalia, Jakarta, Penerbit Ghalia Indonesia, 2001.

Notoatmodjo, Soekidjo. 2003. Pendidikan dan Perilaku Kesehatan. Penerbit Rineka Cipta. Jakarta.

Parlinda, Vera dan M. Wahyuddin. Pengaruh Kepemimpinan, Motivasi, Pelatihan, Dan Lingkungan Kerja Terhadap Kinerja Karyawan Pada Perusahaan Daerah Air Minum Kota Surakarta. http://eprints.ums.ac.id/(diakses tanggal 12 Februari 2017).

Prawirosentono, S. 1999. Sumber Daya Manusia Kebijakan Kinerja Karyawan. Penerbit BPFE. Yogyakarta.

Priansa, DJ. 2014. Perencanaan dan Pengembangan SDM. Penerbit Alfabeta. Bandung.

Rivai, Veithazal. 2005. Kepemimpinan Dan Perilaku Organisasi. Penerbit PT. Raja Grafindo Persada.Jakarta.

Rivai, Veithazal. dan Basri, A.F.M. 2005. Performance Appraisal. Penerbit P.T. Rajagrafindo Persada. Jakarta.

Robbins, Stephen P. 2006. Perilaku Organisasi. Penerbit P.T. Indeks. Jakarta.

Sahid Raharjo. Cara Melakukan Analisis Regresi Multiples dengan SPSS. http://www.spssindonesia.com/2014/02 /analisis-regresi-multipes-denganspss.html (diakses pada tanggal 25 April 2017)

Sedarmayanti. 2009, Tata Kerja dan Produktivitas Kerja. Mandar Maju. Bandung.

Sekaran, Uma. 2003. Research Methods For Business. Fourth Edition.John Wiley \& Sons, Inc. New York.

Siagian, S.P. 2001.Manajemen Sumber Daya Manusia. Cetakan ke 9. Penerbit Bumi Aksara. Jakarta.

Simamora, Henry. 2004. Manajemen Sumber Daya Manusia. Penerbit STIE YKPN. Yogyakarta.

Sugiyono. 2009. Statistika untuk Penelitian. Cetakan Keempat belas. Penerbit Alfabeta. Bandung.

Gujarati, Damodar. 2003. Basic Econometrics. Fourth Edition. McGraw Hill Inc. New York. 
Soeprihanto, John. 2001. Penilaian Kinerja dan Pengembangan Pegawai. Badan Penerbit Universitas Gadjah Mada. Yogyakarta.

Sumarsono, Sonny. 2009. Teori dan Kebijakan Publik: Ekonomi Sumber Daya Manusia. Penerbit Graha Ilmu. Yogyakarta.

Timpe, A. Dale. 2000. Kepemimpinan. Penerbit PT. Elex Media Komputindo. Jakarta.
Prajitiasari, Ema D. Pengaruh Pendidikan dan Pelatihan Pada Karyawan Terhadap Produktivitas Kerja Pada PT Bank Rakyat Indonesia (Persero) Cabang Tulungagung. http://www.stiemahardhika.ac.id/wpcontent/up-loads/2013/01/EMA-1$\underline{15 . p d f}$ (diakses pada tanggal 8 Januari 2017).

Wursanto, IG. 2002. Manajemen Kepegawaian. Penerbit Kanisius. Yogyakarta. 